\title{
Psychological determinants of self-care for health among fathers with small children
}

\begin{abstract}
BACKGROUND
Care of own health is statistically determined by many variables. The authors of the article focused exclusively on objective stable factors such as personality traits and health valuation. The conducted research study aimed at assessment of correlations between self-care for health and its psychological constituents such as personality traits, health locus of control, self-efficacy, positive and negative affect as well as health valuation examined in the population of fathers of small children.
\end{abstract}

\section{PARTICIPANTS AND PROCEDURE}

The examinations included 77 fathers aged between 30 and 40 who filled out the following questionnaires: NEO-FFI Inventory, Generalized Self-Efficacy Scale, Multidimensional Health Locus of Control Scale, Positive and Negative Affect Schedule, List of Criteria for Health, Health Value Scale and Care-for-Health Scale.

\section{RESULTS}

Positive correlations were noted between the general level of individual health self-care (including an active attitude to- wards own health and practices for health) and health valuation, extroversion, conscientiousness, self-efficacy, external health locus of control - influence of others (or powerful others) and positive emotionality. Negative correlations were detected between health self-care (in general and within particular health scales) and neuroticism and negative affect. The following factors proved statistically significant for self-care for health: health valuation, personality traits, and external health locus of control - influence of others.

\section{CONCLUSIONS}

In the selected group of men the strongest correlation between health self-care and health valuation both in physical (practices for health) and psycho-social (active attitude toward own health) aspects was observed. Ascertaining health self-care predictors can be useful for constructing health self-care promotion programs to address the parents of small children.

\section{KEY WORDS}

health locus of control; personality traits; self-care for health; valuation of health; positive and negative affect

organization - Faculty of Christian Philosophy, Institute of Psychology, Cardinal Stefan Wyszyński University, Warsaw, Poland

AUthors' CONTRibutions - A: Study design - B: Data collection - C: Statistical analysis - D: Data interpretation . E: Manuscript preparation · F: Literature search · G: Funds collection

Corresponding Author - Paulina Rosińska, Ph.D., Faculty of Christian Philosophy, Institute of Psychology, Cardinal

Stefan Wyszyński University, 1/3 Wóycickiego Str., 01-938 Warsaw, Poland, e-mail: rosinskapaulina@gmail.com

TO CITE THIS ARTICLE - Rosińska, P., \& Tylka, J. (2016). Psychological determinants of self-care for health among fathers

with small children. Health Psychology Report, 4(3), 202-212. doi: 10.5114/hpr.2016.57684

RECEIVED 06.11.2015 · REVIEWED 06.12.2015 · ACCEPTED 11.01.2016 · PUBLISHED 07.03.2016 


\section{BACKGROUND}

Thorough investigation of behaviors associated with individual care of health (shown by parents of small children) and the review of recent research studies concerning various factors (such as neuroticism, extroversion, self-efficacy, health valuation, and positive emotionality) of pro-healthy behaviors contributed to exploring the issues associated with health self-care.

It was found that the results of many research studies were ambiguous, which became a direct reason for this research study. The authors of the article focused on stable subjective factors (personality traits, health valuation), cognitive factors (self-efficacy, locus of health control) and emotionality.

Undertaking the issue of behaviors in favor of health regarded as the conditions closest to the state of health challenges social needs (Heszen \& Sęk, 2015; Jacennik, 2008; Murphy, 2005). Civilization diseases are still the main cause of the high mortality rate. Every year there are more and more people falling sick with malignant tumors, diabetes, asthma and hypertension. Depression is the most common problem of psychological health in Europe, and $18 \%$ of the total population suffers from depression in Poland (Statistics in Poland from 2013; Santulli, 2013).

Various diseases and disorders appear to develop because of too rapid progress of civilization. Considerable progress of technology, urbanization and industrialization as well as too rapid pace of social changes can cause stress when contemporary man is maladapted for constantly new and dynamically changing ontological conditions. The above-mentioned diseases are the cause of considerable social problems bringing about premature deaths, disabilites and job absence, including high costs of medical treatment (Betlejewski, 2007; Carrera-Bastos, Fontes-Villalba, O’Keefe, Lindeberg, \& Cordain, 2011).

Numerous data from the relevant literature justify a pro-healthy lifestyle (physical activity, proper diet and coping with stress) as the basis for health and efficient protection against civilization diseases. It was documented that improper diet, smoking cigarettes, drinking alcohol, lack of exercise, excessive sun exposure, and long-term stress with incapability of coping with are important dangers causing carcinoma and circulatory diseases (Milham, 2010).

Forming pro-healthy behaviors contributes both to improving an individual state of health by the impact on quality of life and the entire population with its social system of healthcare (Crockett, 2007; Gromulska, Piotrowicz, \& Cianciara, 2009; Jacennik, 2008; Ogińska-Bulik, 2010; Murphy, 2005).

Creation of a certain image of health care in the group of fathers in view of the fact that parents shape healthy behaviors of their offspring is a challenge worth paying attention to. An improper lifestyle of parents is a crucial risk factor associated with civilization diseases (more and more children at kindergarten age suffer from obesity, hypertension and/or diabetes) (Hearst, Martin, Rafdal, Robinson, \& McConnellc, 2013; Khanolkar, Byberg, \& Koupil, 2012; Ogińska-Bulik, 2010)

The present examinations constitute one of the elements in the wider long-term project on measuring behaviors associated with health self-care in various groups. It is planned to conduct such examination also with the children of these parents to prove a relevant correlation between the current healthy behavior of parents and the future self-care for health undertaken by their children.

Defining self-care of health can be understood as a "positive attitude toward own health including any forms of pro-healthy activity” (Rosińska, 2014, p. 37).

Self-care for health care means a concern about own health not only during sickness, and persons who care about their health are responsible for themselves. In the structure of health self-care one can find three correlating aspects: cognitive, emotional and behavioral. The cognitive aspect assumes perception of health not only as a value (intended state or target) but a value highly located in the hierarchy. The emotional aspect is expressed by objective anxiety about the health state or satisfaction of keeping fit. Finally, the behavioral aspect covers all activities conducted in favor or physical and psycho-social health (called pro-healthy behaviors) (Rosińska, 2014).

In the relevant literature one can find various reasons for behaviors associated with health. Due to a huge quantity of variables the authors focus their attention on the stable subjective factors as psychological constituents of health self-care.

When following the opinions of most authors the basis for health motivation is valuation of health. People for whom health is the most important value in their life located it almost at the top of the hierarchy. They are more engaged in pro-healthy behaviors (Lau, Hartman, \& Ware, 1986; Malik, Zarzycka, Iłżecka, \& Jarosz, 2009; Norman \& Bennett, 1996; Stachowska, Gostek, Klimberg, \& Zielińska, 2006). However, the results of other research studies show that a regard for health as a precious value and the knowledge about risk factors concerning loss of health and behaviors aiming at protection and improvement of health are not sufficient for starting to take care about personal health (Biernat, Poznańska, \& Gajewski, 2012; Gętek, Czech, Całyniuk, Białek, \& Kukielczak, 2011).

It is known from the literature that besides attributing a great role to health, factors such as personality traits, self-efficacy, locus of health control, and positive emotionality can also guarantee a choice of pro-healthy behaviors (Bandura, 2007; Folkman
Psychological determinants of self-care for health 
Paulina Rosińska, Jan Tylka
\& Moskowitz, 2000; Heszen \& Sęk, 2015; Juczyński, 2009; Murphy, 2005; Schwarzer, 2008; Steptoe \& Wardle, 2001).

The basic purpose of this research study was to search psychological constituents of health self-care confined to situations when such health self-care is manifested in pro-healthy behaviors of fathers of small children. Activities favoring health and various ways of defining health were also regarded as important.

The following questions for this research study were formulated:

1. Is self-care for health more closely related to personality variables (such as personality traits, self-efficacy, locus of health control) or with valuation of health?

2. What determinants can be useful in predicting the general level of health care? Do the same variables constitute care of physical and psychosocial health?

In response to these questions the following hypotheses were formulated:

H1. It is assumed that there are characteristic dependencies between selected personal traits, self-efficacy, locus of health control, positive and negative emotionality as well as valuation of health and symptoms of healthcare.

H2. Valuation of health, selected personality traits, feelings and type of locus of health control are relevant predictors of healthcare.

\section{PARTICIPANTS AND PROCEDURE}

Men aged between 30 and $40(N=77)$ participated in this research study. All of them graduated from higher schools. Exclusively the fathers of small children (aged up to 5) exhibiting good health were included in the examination (the subjective criterion was self-esteem of health and the objective criterion was lack of diagnosed long-term disease). Moreover, the subjects had not experienced severe pain within recent months.

These examinations were conducted in Warsaw kindergartens and kids' clubs from January to February 2015. The examined men were informed about the purpose of the study and some of them (who asked for it) were given a short interpretation of results. The examinations had an individual character. In most cases it took about half an hour for the subject to fill out all the questionnaire.

The acquired data were subjected to statistical calculation using the SPSS package. Pearson's correlation coefficient $(r)$ and regression analysis were used in the calculations.

Measurement of independent variables employed the following tools: NEO-FFI Costa and McCrae Inventory (neuroticism, extroversion, agreeableness, openness to experience, conscientiousness); Generalized Self-Efficacy Scale (GSES) by Schwarzer et al. (self-efficacy); Multidimensional Health Locus of Control Scale - MHLC by Wallston et al. (internal and external locus of health control); Positive and Negative Affect Schedule - SUPIN by Brzozowski (positive and negative feelings); Health Value Scale (HVS) by Lau et al. (health valuation); List of Health Criteria by Juczyński (definitions of health). The above-described tools are characterized by satisfactory psychometric qualities (Brzozowski, 2010; Juczyński, 2001; Zawadzki, Strelau, Szczepaniak, \& Śliwińska, 1998).

The dependent variable was examined with the Care-for-Health Scale (CHS) by Rosińska. This scale includes the general level of self-care for health, active attitude toward own health and practices for health. The first factor as an active attitude toward own health groups behaviors in the psycho-social aspect (formulation of goals, tasks, actively solving problems, care about relations with other people). The second factor (pro-healthy practices) includes the items of the scale referring to the physical aspect (for instance, visits for check-up examinations, proper diet, and behaviors associated with sleep).

The survey was constructed for the purpose of research studies on health self-care among parents of children of various ages. The basis for construction of the Care-for-Health Scale is a wide definition of pro-healthy behaviors by Gochman to cover various groups of behavior (objective and habitual or pertaining to the personal traits spectrum).

The scale contains 10 items referring to various activities - examples of health self-care. Frequency of occurrence of particular behaviors is estimated on a four-level scale (0-4 or 4-0). The subject answers a question how often he/she performs a certain activity (almost never, sometimes, often, very often, almost always, almost everyday). In some cases of responses the level is reversed. A value of a general indicator of health self-care intensity is between 0 and 40. A person obtaining high results in the Carefor-Health Scale is characterized by a higher level of individual care about own health.

The internal consistency of the Care-for-Health Scale when evaluated using the Cronbach $\alpha$ reliability coefficient was between .67 and .73 for various groups. The more questions in the scale, the higher was Cronbach's $\alpha$. This scale is a short questionnaire measuring heterogeneous qualities, so in this context it is reasonable to assume that the above values of $\alpha$ statistics are acceptable.

At the initial stage of research the accuracy of this scale was assessed by comparing its scores with the Inventory of Healthy Behaviors by Juczyński (2001). The strongest correlations were noted between the general level of health self-care and: positive psychological attitude $(.62, p<.001)$, global score of healthy 
behaviors intensification $(.59, p<.001)$, proper nutrition habits $(.53, p=.002)$, prophylactic behaviors (.47, $p=.003)$ and health exercises $(.42, p=.003)$. The test-retest was also conducted after 8 weeks and the obtained coefficient of correlation value was .75 $(p<.001)$ (Rosińska, 2014).

The data from a personal questionnaire were also used for exclusion of persons with pain troubles or chronic disease from the examined group and to create the image of health self-care in the selected group of men.

\section{RESULTS}

Before verifying the appropriate hypotheses by the descriptive statistics, the image of perceiving (defining) health including the most frequent and rarest pro-healthy behaviors of fathers of small children was obtained.

The way the examined persons defined health was estimated using the Health Criteria List.

The majority $(82 \%)$ of examined persons when asked what it means to be healthy chose out of 24 categories only those that reflected the understanding of health as quality. Such a way of perceiving health included the following descriptions: for all parts of the body to be efficient, not to have to visit a doctor, not to be sick with the exception of flu or indigestion, not to feel any physical troubles, only sometimes to take medicaments. All the above statements describe health in the physical aspect.

At the second position concerning frequency of responses, $60 \%$ of subjects chose descriptions of health understood as a state. These were statements

\section{Table 1}

Coefficients of correlation between: personality traits, feelings, external locus of health control - influence of others, self-efficacy, valuation of health and the general level of health self-care (CHS), active attitude toward own health (CHS 1) and practices for health (CHS 2)

\begin{tabular}{lccc}
\hline Constituents & CHS & CHS 1 & CHS 2 \\
\hline NEU & $-.29^{* *}$ & $-.52^{* *}$ & -.01 \\
EXT & .19 & $.40^{* *}$ & -.02 \\
CONS & .16 & $.35^{* *}$ & -.05 \\
PF & $.23^{*}$ & $.34^{* *}$ & .11 \\
NF & -.07 & $-.28^{*}$ & .16 \\
MHLC-I & $.35^{* *}$ & .11 & $.36^{* *}$ \\
GSES & .06 & $.31^{* *}$ & -.19 \\
HVS & $.60^{* *}$ & $.46^{* *}$ & $.52^{* *}$ \\
\hline
\end{tabular}

Note. ${ }^{*} p<.05,{ }^{* *} p<.01$ such as to feel happy most of the time, to be able to enjoy life, and to feel well. They concern psychological health but can also refer to the somatic sphere.

Based on the Scale of Health Self-Care as a tool and relying on particular questions from the personal questionnaire the image of health self-care in fathers of small children was created.

A majority of fathers of small children (72\%) rarely or almost never attended medical check-up examinations, whereas $6 \%$ of men regularly attended such routine examinations.

In the studied group of men only $15 \%$ of them performed various daily physical exercises. Surprisingly, $41 \%$ of subjects admitted that they rarely or never perform physical activity.

Activities concerning the physical aspect of health self-care exhibit the following statistics: $45 \%$ of the subjects stated that they try healthy food. More than half $(52 \%)$ of subjects occasionally or never ate meals in fast food restaurants. More than $76 \%$ rarely took stimulants (broadly defined). More than half of this population of men reported a lack of problems with sleeping (quality or quantity).

Almost half of the examined men occasionally applied for social aid. In this context it is obvious that more than $45 \%$ of men claimed frequent striving for perfection (quotation from interview "I must do everything on my own"). Half of investigated persons almost never followed any religious practices (attendance in services, prayers, meditations). Nearly onethird $(31 \%)$ of fathers stated that they often and/or daily followed religious practices to complete their self-care of health.

On the one hand, $60 \%$ of the subjects claimed that they almost always solve daily problems, but on the other hand, half of the examined fathers rarely assumed real goals. More than $82 \%$ of men almost never or occasionally experienced anxiety strain, and half of them rarely experienced lack of anger control. Most of the fathers $(68 \%)$ declared daily care about social contacts.

In order to verify the first hypothesis, an estimation of Pearson's $r$ linear correlation was performed. Statistically significant positive correlations were found between the general level of self-care for health (CHS) with its components such as active attitude toward own health (CHS 1), practices for health (CHS 2) and extroversion (EXT), conscientiousness (CONS), positive feelings (PF), external locus of health control - influence of others (MHLC-I), self-efficacy (GSES) and valuation of health (HVS). Negative correlations were observed between the health self-care and its components such as neuroticism (NEU) and negative feelings (NF). Table 1 shows exclusively statistically significant correlations (of particular variables with at least one sub-scale of the $\mathrm{CH}$ Scale).

The highest values of correlation coefficients were obtained between health valuation and the general level of health self-care, active attitude toward own
Psychological determinants of self-care for health 
Paulina Rosińska, Jan Tylka health as well as practices for health. External locus of health control - influence of others and positive feelings were positively associated with the general level of health self-care, whereas this association was statistically negative in the case of neuroticism. A person obtaining high results in the $\mathrm{CH}$ Scale attributes high importance to own health and is characterized by emotional stability and frequent experiences of positive emotions. Furthermore, such a person is susceptible to impacts of other persons (conclusions of physicians at check-up examinations).

Neuroticism most strongly correlates with an active attitude toward own health (care of psycho-social health) and then extroversion, conscientiousness, positive, negative affect, and sense of self-efficacy. Hence, it is reasonable to assume that an individual who cares about his/her own psychosocial health is emotionally balanced, social and likely to experience more positive than negative emotions. Moreover, such a person is characterized by strong perception of own competence, internal order and conscientiousness.

The scores concerning pro-healthy activity (area of physical health) are associated only with external locus of health control - influence of others. Persons who care about their physical health also obtain high scores in the MHLC-I Scale, which means that other people have an impact on their decisions associated with health.

The considered correlations were gained in relation to certain behaviors to observe precisely the relations between the independent variables and the indicators of self-care for health.

Attribution of a high value to human health was associated with activities such as care of social contacts $(r=.40, p=.001)$, participation in regular medical examinations $(r=.32, p=.002)$, religious practices $(r=.32, p=.004)$, physical activity $(r=.31$, $p=.006)$, lack of psychological strain $(r=.27$, $p=.016)$, pro-healthy diet/nourishment $(r=.26$, $p=.022)$, and sleeping $(r=.26, p=.025)$.

Experiences of positive feelings correlated with choices of real, certain goals $(r=.29, p=.027)$ and occasionally experiencing psychological strain/tension $(r=-.26, p=.023)$. The negative emotion scores were inversely proportionally correlated with emotional stability - lack of psychological strain $(r=.53, p=.001)$.

Some interesting results concern the correlation of particular pro-healthy behaviors with personal traits. In the basic correlations no association with agreeableness, openness to experience, or conscientiousness was observed, but the operations conducted using items describing certain behaviors revealed associations between health-related activities and these traits.

Agreeableness correlated with an ability to seek social support $(r=.30, p=.009)$. Statistically significant correlations were noted between openness to experience and healthy nourishment $(r=.34$, $p=.002)$, and more and more rare feeling of anger $(r=.29, p=.011)$. A correlation between conscientiousness and proper nourishment $(r=.30, p=.008)$, lack of stress $(r=.33, p=.003)$ but with an inclination to perfectionism $(r=.27, p=.019)$ was observed. Extroversion was associated with very rare feeling of psychological strain $(r=.32, p=.003)$ and care about social contacts $(r=.32, p=.003)$. Nevertheless, the greatest amount of significant associations was detected between neuroticism and particular behaviors such as engagement in sport $(r=-.29, p=.010)$, formulation of certain real goals $(r=-.26, p=.021)$, rare experiences of anger $(r=-.37, p=.001)$ and psychogenic strain $(r=-.55 p=.001)$ and care of social contacts $(r=-.27, p=.019)$.

Among the three types of health control location exclusively an external locus - influence of others was associated with pro-healthy behaviors such as regular medical check-up $(r=.43, p=.001)$, good quality and quantity of sleeping $(r=.28 p=.014)$.

There were found associations between self-efficiency perception and preferring personal obligations to interpersonal contacts $(r=-.36, p=.001)$ and attending religious services $(r=.28, p=.004)$.

The analysis of multivariable regression (statistics F) was applied to verify the second hypothesis. Conditions for applying a statistical regression were tested during the research program completion. Selection of variables was closely associated with magnitude of the correlation coefficient obtained from the analysis of correlation. The following variables were taken into account: health valuation, selected personality traits, positive and negative emotions, external locus of health control - influence of others.

The four constituent model was made to explain the general level of health self-care. It proved statistically significant $(F(4,72)=19.01, p<.001)$ and the corrected coefficient $R^{2}$ value was $.49(R=72$, $\left.R^{2}=.52\right)$. It means that based on the below described coefficients it is possible to explain $49 \%$ of variance of the dependent variable. The variables that proved statistically significant to influence the general level of health self-care are valuation of health, external locus of control - influence of others, neuroticism and negative feelings. The first model (covering only valuation of health) explained up to $34 \%$ of variable variance (a higher percentage than the sum of other predictors percentage). Relations between predictors and the explained variable are statistically significant and $\beta$ coefficients are shown in Table 2.

The presented model for predicting an active attitude toward own health proved statistically significant $(F(3,73)=19.62, p<.001)$ and the corrected coefficient $R^{2}$ value was $.42\left(R=69, R^{2}=.45\right)$. It is possible to explain $42 \%$ of dependent variable variance. The following variables are useful for prognosticating an active attitude toward own health such as neu- 
Table 2

Results of regression analysis for predictors of the general level of health self-care

\begin{tabular}{lcccc}
\hline Indicators & Coefficient b & $\begin{array}{c}\text { Standardized } \\
\text { coefficient } \beta\end{array}$ & $t$ & $p$ \\
\hline Health valuation & .61 & .50 & 5.80 & .001 \\
$\begin{array}{l}\text { External locus of health control influence } \\
\text { of others }\end{array}$ & .29 & .32 & 3.76 & .001 \\
Neuroticism & -.27 & -.42 & -3.78 & .001 \\
Negative feelings & -.17 & -.26 & 2.44 & .017 \\
\hline
\end{tabular}

Table 3

Results of regression analysis for predictors of active attitude toward own health and pro-healthy practices

\begin{tabular}{|c|c|c|c|c|}
\hline Indicators of active attitude toward own health & Coefficient $b$ & $\begin{array}{c}\text { Standardized } \\
\text { coefficient } \beta\end{array}$ & $t$ & $p$ \\
\hline Neuroticism & -.13 & -.34 & -3.40 & .001 \\
\hline Health valuation & .28 & .35 & 4.31 & .001 \\
\hline Extroversion & .10 & .23 & 2.36 & .021 \\
\hline Indicators of pro-healthy practices & Coefficient b & $\begin{array}{l}\text { Standardized } \\
\text { coefficients } \beta\end{array}$ & $t$ & $p$ \\
\hline Health valuation & .40 & .47 & 4.91 & .001 \\
\hline $\begin{array}{l}\text { External locus of health control influence } \\
\text { of others }\end{array}$ & .17 & .28 & 2.90 & .005 \\
\hline
\end{tabular}

roticism, health valuation and extroversion. Dependencies between these predictors and the explained variable are statistically significant and $\beta$ coefficients are presented in Table 3 .

The model suggested for predicting pro-healthy practices proved statistically significant $(F(2,74)=19.21$, $p<.001)$ and the corrected coefficient $R^{2}$ value was $.32\left(R=58, R^{2}=.34\right)$. The two predictors valuation of health and external locus of control - influence of others explain $32 \%$ of variance of the dependent variable. Relations between predictors and this explained variable are statistically significant (Table 3 ).

Predictors of an active attitude toward own health and practices for health are shown in one Table 3. It favors an effective comparison of the determinants of psycho-social and physical care of health.

\section{DISCUSSION}

In the beginning it was shown how health was defined by the selected group of fathers and also created an image of health behaviors most and least adopted. Getting familiar with understanding health by individuals or groups is one of the reasons for gaining success in the actions planned in favor of health promotion. Depending on the way of understanding the term "to be healthy", persons may prefer vari- ous healthy behaviors. For instance, one person cares about developing efficient methods of coping with stress or difficult emotions and someone else puts emphasis on proper nourishment (diet).

The main purpose of this study was to research the determinants of health self-care by assessment of associations between health self-care and selected psychological variables.

The results of the study allowed verification of assumptions involved in the hypothesis. Hypothesis $\mathrm{H} 1$ that assumed characteristic correlations between selected personality traits and self-efficacy, location of health control, positive and negative emotionality, health valuation and signs of individual care of health was confirmed. The results obtained from the regression analysis favored adoption of hypothesis $\mathrm{H} 2$ indicating a considerable role of valuation, personality traits, experienced feeling and type of health control location when predicting self-care of health.

In all the independent variables constituting health self-care (both at the general level of health self-care and in the sub-scales) valuation of health showed the strongest correlations. The results of this study accurately correspond to the theoretical assumptions on the nature of health self-care and its constituents (Rosińska, 2014). These results are inscribed in the research trend to regard valuation of health as an important variable associated with
Psychological determinants of self-care for health 
Paulina Rosińska, Jan Tylka a choice of pro-healthy behaviors (Dolińska-Zygmunt, 2001; Malik et al., 2009; Stachowska et al., 2006; Weiss \& Larsen, 1990). According to Lau et al. (1986), Norman and Benet (1996), Ogińska-Bulik (2010) the persons attributing some more value to health prove more frequent engagement in taking actions promoting health such as accurate nourishment habits, obeying diet, quitting cigarettes, medical inspection of the breast, and safety of journeys (e.g. fastening seat belts in vehicles). Moreover, the high level of health valuation favors obeying medical recommendations, gaining information about health and diseases and positive emotional attitudes (avoiding strong fear, anger) and pro-healthy practices (sleeping, recreation, physical activity).

The obtained results favor formulation of a more accurate response to the ambiguous associations between pro-healthy behaviors and health valuation. The conducted analysis means that for the selected group of fathers health is not only a matter of attributing a high value as a declaration but it is associated with real behaviors. When analyzing the obtained experimental data, harmony was observed between a declared system of values (most of the examined subjects placed health in the highest positions) and coefficients reflecting their self-care of health.

Neuroticism was the next variable strongly associated with the general level of health self-care and an active attitude toward health. The obtained results favor formulation of a thesis about the relation of this personal trait high intensity - in general - with worse psycho-social functioning (frequently experiencing internal strain, ambivalent emotional states, inefficient coping with difficult situations). Neurotic persons are too strongly focused on their feelings, defeats and difficulties. Such a state of chronic psychological strain disables relations with others so they probably can less efficiently care about interpersonal contacts. A focus on the future with a tendency to worry or anxiety approach does not favor determining real personal targets. The obtained results correspond with the variety of scores in the relevant literature that unambiguously indicate a negative correlation between neuroticism and healthy behaviors - mainly in the field of stimulants and improper coping with stress (Booth-Kewley \& Vickers, 1994; Friedman, Kern, \& Reynolds, 2010; Smith, 2006).

A positive correlation between extroversion and care of health was revealed but exclusively in the context of taking care about psycho-social health. Persons characterized by high intensity of this trait were cordial and social, which may favor their concern about proper social relations. Extroverts are famous for considerable vital dynamism, vitality and experiencing many positive emotions. The particular components of extroversion let these persons take decisions fast and cope better with stress situations for instance more frequent use of available support.
Results from the above analysis correspond with the research studies in the relevant literature showing that extroversion is associated with pro-healthy activities such as choice of effective methods of coping with stress in difficult situations and taking reasonable actions oriented toward solution of problems as well as inclination for choosing the (real) goals possible to be achieved (Booth-Kewley \& Vickers, 1994; Conway, Vickers, Wallston, \& Costa, 1992; Friedman et al., 2010).

The next personality trait - conscientiousness corresponded with an active attitude toward own health at the level of correlations with particular behaviors including proper nourishment. The results of this study were similar to the results of other researchers (Bogg \& Roberts, 2013; McCann, 2005; Raynor \& Levine, 2009), indicating a positive association between conscientiousness and preferring pro-healthy activities (e.g. eating many fruits and vegetables, regular sleeping, use of seat belts in cars, physical activity). Components such as self-discipline and self-obligation are bound to be helpful in physical training or following a recommended diet. Attempts of striving for achievements and competence are precious in solving daily problems, and they allow precise formulation of real goals, whereas the inclination to keep order and settled rules is probably helpful in planning and managing a daily schedule (date of medical check-up, keeping fixed hours of sleeping). In spite of the fact that the vast majority of research studies confirm associations between conscientiousness and pro-healthy style of life it is worth keeping in mind that the high level of this trait is an essential component of perfectionism dangerous for psycho-physical balance. The procedure of statistical correlation of behavior resulting from perfectionism was applied and it turned out to be associated with conscientiousness.

Experiencing positive feelings was associated with the general level of health self-care and an active attitude toward own health. Positive affectation is helpful with creating various social behaviors (care of social ties, performing various roles, exposing a need of support) and it is also an indicator of subjective state of individual well-being. Persons who often experience pleasant emotional states are usually psychologically healthy and their better being in healthy form is mainly associated with a choice of pro-healthy behaviors. They are characterized by lower psychological strain and can neutralize negative emotions such as anger or frustration (Heszen \& Sęk, 2015). Fredickson's conception (2013) called the theory of widening the mind and building resources can bring answers concerning the character of relations between positive emotions and health self-care. Positive emotionality plays an important role in proper functioning of human beings in various areas and dealing with daily problems. An ability 
of integrating a variety of information is developed by experiencing positive psychological states. Elasticity and efficiency of thinking are also better, and are undoubtedly essential in the process of determining real goals and active managing of situations.

On the other hand, negative emotionality was correlated with health self-care in the field of active attitude toward own health. Negative emotions cause insufficient attention and stiffness of thinking to lead this way to limited activity. From the evolutionary perspective such a scheme is relevant (fight or escape), but for a pro-healthy style of life it can mean a persistent choice of anti-healthy behaviors (psychological tension/strain means overeating).

The results of this study confirm the result of other authors. Positive emotions are matched with choices of strategies focused on a task (problem), whereas negative emotions often become predictors of less adaptive styles (Folkman \& Moskowitz, 2000; Fredrickson, 2013).

Statistically significant correlations were noted in the field of active attitude toward own health and self-efficacy. Personal competence has an impact on individual choice and the decision about an undertaken activity, effort put into this activity, perseverance, way of success and defeat attribution (Bandura, 2007). Therefore it is reasonable to conclude that persons characterized by a high level of self-efficiency would be systematically engaged in sport. The results of numerous studies indicate that self-efficiency is a good predictor of physical activity (Papandonatos et al., 2012).

Persons who are convinced that they can undertake activity and this way solve any problem are characterized by stronger motivation to do it, and they are more engaged in the decision-making process. High self-efficacy corresponds with choosing ambitions and real purposes. The statement "I tried but I failed" is not a reason to worry for persons regarding themselves as competent, but it is a challenge and motivation for making more effort. Such a way of thinking may favor seeking many new solutions of daily problems and determining real targets of life. Therefore, it is possible to predict that in case of defeat a person with a strong sense of competence would not feel an excessive psychological strain and frustration that in turn can lead to other risky ways of behavior (Bandura, 2007; Schwarzer, 2008).

A positive correlation between locus of health control was also confirmed but exclusively in external locus of health control - influence of others. An important correlation was observed in each group not only in terms of simple dependency but also the regression analysis proved that locating health control sources by the examined subject in other persons is a considerable predictor of caring about them. Such a kind of external control of health may favor obeying recommendations of physicians concerning quantity and frequency of medical examinations, and generally better sensitivity to environmental impacts (posters advertising pro-healthy campaigns, or family suggestions). It is an interesting result because the connection between healthy behaviors and solely internal location of health control is abundantly documented as evidence for the population of healthy people (Conway et al., 1992; Ingledew \& Brunning, 1990; Wallston $\&$ Wallston, 1978). The relation between external location of health control - other impacts and preferring pro-healthy behaviors quoted from Kurowska and Lewandowska (2012) is observed in the group of sick people. A disease as a difficult situation is a source of stress for an individual. An approach to parenthood from the perspective of situations causing stress assumes that parents face a series of new and difficult circumstances and challenges raising tension (e.g. performance of new role, attempt of compromising between own expectations and needs of children, various anxieties associated with children's health). In such a period an external location of control can play a more important role in a pro-healthy style of life. Perhaps it is a specific time when support from other people and seeking various sources of support favors pro-healthy behaviors. It is also likely that an external location of health control favors - for instance participation of parents in psychological workshops, relying on opinions of medical experts concerning children's and parents' health.

The conducted analysis of regression favored setting aside the factors helpful for explaining health self-care. According to the previously mentioned results the strongest predictor was attribution of high value to health almost in each analyzed model as it was assumed. Hence, it is reasonable to conclude that the persons perceiving their health as a value would care about it both in physical and psycho-social aspects. An important clue is the fact that the impact of this variable exceeded the summary effect of other variables. Thus it would be possible to assume that an accurately formed system of individual values where health is at the top of appreciation is a specific guarantee of healthy behaviors. Does health - life of children immediately after birth seem to be a higher value?

Apart from health valuation the statistically significant constituents in relation to the general health self-care proved an external locus of health control - influence of others and also strongly associated factors - neuroticism and negative feelings. It favors the conclusion that an individual highly appreciating his/her health follows advice and suggestions of other people. Moreover, such a person is characterized by emotional stability and rare experiencing of unpleasant emotional states and is inclined to choose behaviors advantageous for health.

Neuroticism (with its negative statistical value) proved the strongest constituent for predicting be-
Psychological determinants of self-care for health 
Paulina Rosińska, Jan Tylka haviors associated with psycho-social health (active attitude toward own health). Apart from neuroticism, valuation of health and extroversion was as significant. Therefore it is reasonable to suppose that an emotionally balanced person would care more about health in the sphere of psychological and social functioning. Attempts of learning accurate prohealthy activities such as choice of efficient strategies of coping with stress can be difficult due to the fact that both neuroticism and extroversion are traits determined by biology.

A system containing solely two predictors proved very significant for explaining pro-healthy practices - valuation of health and external location of health control - other impacts. Furthermore, this model was the worst for explaining changeability in the considered variance. It is very likely that motivation to undertake activities associated with physical health such as nourishment, medical check-up visits, and proper quantity and/or quality of sleeping depends on diametrically different factors, which can be more external - for instance situational ones.

\section{CONCLUSIONS}

1. Valuation of health was most strongly associated with health self-care (both at the general level and within the sub-scales). It was also the best factor for predicting the general level of health self-care and pro-healthy practices (self-care of physical health). Health valuation is an important predictor of health self-care both in the group of fathers of small children who graduated from high school and in the group of mothers. Therefore this variable can be best for predicting prohealthy behaviors regardless of sex and age (Rosińska, 2014).

2. The general level of health self-care can be outlined by valuation of health, external locus of health control - influence of others, neuroticism and negative feelings (negative correlations).

3. The level of active attitude toward own health can be predicted with the use of neuroticism, health valuation, and extroversion. Practices for health can be explained with the following variables: valuation of health and external locus of health control - other impacts.

4. Pro-healthy behaviors in the scope of psycho-social health (active attitude toward own health) are explained by other variables (relatively durable) different from the variables explaining pro-healthy behaviors in terms of physical health (practices for health).

5. It is worth referring the sources of knowledge about health self-care to the bigger population.

Ascertaining health self-care predictors is bound to be a step forward to developing programs of health promotion addressing the parents of small children. When planning the research studies corresponded with the trend of pro-healthy behaviors prophylaxis it is worth keeping in mind the practical aspects such as schedule of training sessions or workshops that would finally shape pro-healthy behaviors in the family mode/style. It would be based on learning and developing individual resources closely related to health self-care. For example, activities associated with learning a fear and tension decrease or exercises for improvement of coping with difficult situations (request for support) would be included in the framework of workshop for parents. A change in behaviors also demands gaining certain competences enabling a person to know what activity is to be done but also how to follow them (e.g. to follow a diet, to maintain health self-esteem). A program ought to be an integrated part of activity offered by schools of delivery or workshops for young parents and also at places where it is possible to spend time with a child (kids' clubs).

\section{References}

Bandura, A. (2007). Teoria spotecznego uczenia się [Social Learning Theory]. Warszawa: Wydawnictwo Naukowe PWN.

Betlejewski, S. (2007). Choroby społeczne, cywilizacyjne czy choroby stylu życia? [Social and civilization diseases or lifestyle diseases?]. Wiadomości Lekarskie, 60, 9-10.

Biernat, E., Poznańska, A., \& Gajewski, A. (2012). Determinanty prozdrowotnej aktywności fizycznej warszawskich nauczycieli [Determinants of health physical activity in Warsaw teachers]. Przeglad Epidemiologiczny, 66, 119-126.

Bogg, T., \& Roberts, B. W. (2013). Conscientiousness and health-related behaviors: a meta-analysis of the leading behavioral contributors to mortality. Psychological Bulletin, 130, 887-919.

Booth-Kewley, S., \& Vickers, R. R. (1994). Associations between major domains of personality and health behavior. Journal of Personality, 62, 281-298.

Brzozowski, P. (2010). Skala Uczuć Pozytywnych i Negatywnych SUPIN [Positive and Negative Affect Schedule]. Warszawa: PTP.

Carrera-Bastos, P., Fontes-Villalba, M., O’Keefe, J. H., Lindeberg, S., \& Cordain, L. (2011). The western diet and lifestyle and diseases of civilization. $R e$ search Reports in Clinical Cardiology, 2, 15-35.

Central Statistical Office of Poland. (2013). Zdrowie i ochrona zdrowia w 2012 roku [Health and Health Protection in 2012]. Warszawa: Główny Urząd Statystyczny. Departament Badań Społecznych i Warunków Życia. Zakład Wydawnictwa Statystycznych.

Conway, T. L., Vickers, Jr. R. R., Wallston, K. A., Costa, Jr. P. T. (1992). Personality, Health Locus of Control, 
and Health Behavior. Poster presented at the Annual Convention of the American Psychological Association, 100 ${ }^{\text {th }}$, Washington, DC, August 14-18, 1992. Source: http://files.eric.ed.gov/fulltext/ED353503. pdf (20.09.2012).

Crockett, R. (2007). Health behaviour. The Parliamentary Office of Science and Technology. Postnote. May, number 283.

Dolińska-Zygmunt, G. (2001). Podstawy psychologii zdrowia [Bases for health psychology]. Wrocław: Wydawnictwo Uniwersytetu Wrocławskiego.

Folkman, S., \& Moskowitz, J. T. (2000). Positive affect and the other side of coping. American Psychology, 55, 647-654.

Fredrickson, B. L. (2013). Updated thinking on the positivity ration. American Psychologist, 68, 814822.

Friedman, H., Kern, L., \& Reynolds, C. A. (2010). Personality and health, subjective well-being, and longevity. Special Issue: Trait Anger and Reactive Aggression. M. D. Robinson \& Benjamin M. Wilkowski (eds.). Journal of Personality, 78, 179-216.

Gętek, M., Czech, N., Całyniuk, B., Białek, A., \& Kukielczak, A. (2011). Świadomość zdrowotna społeczeństwa a dbałość o zdrowie [Health awareness of community versus health self-care]. Polski Przeglad Nauk o Zdrowiu, 1, 14-20.

Gromulska, L., Piotrowicz, M., \& Cianciara, D. (2009). Własna skuteczność w modelach zachowań zdrowotnych oraz w edukacji zdrowotnej [Self-efficacy in models of health behaviors and health education]. Przeglad Epidemiologiczny, 63, 427-432.

Hearst, M. O., Martin, L., Rafdal, B. H., Robinson, R., \& McConnellc, S. R. (2013). Early childhood development and obesity risk-factors in a multi-ethnic, low-income community: Feasibility of the 'Five Hundred under Five' social determinants of health pilot study. Health Education Journal, 72, 203-215.

Heszen, I., \& Sęk, H. (2015). Psychologia zdrowia [Health Psychology]. Warszawa: Wydawnictwo Naukowe PWN.

Ingledew, D. K., \& Brunning, S. (1999). Personality, preventive health behaviour and comparative optimism about health problems. Journal of Health Psychology, 4, 193-208.

Jacennik, B. (2008). Strategie dla zdrowia. Ksztattowanie zachowań zdrowotnych poprzez środowisko [Strategies for health. Shaping health behaviors by the environment]. Warszawa: Wyższa Szkoła Finansów i Zarządzania.

Juczyński, Z. (2001). Narzędzia pomiaru w promocji i psychologii zdrowia [Measurement tools in the promotion and health psychology]. Warszawa: Pracownia Testów Psychologicznych.

Juczyński, Z. (2009). Pomnażanie i wzbogacanie zasobów wtasnego zdrowia [Increasing and enrich- ing resources of own health]. Polskie Forum Psychologiczne, 14, 17-31.

Khanolkar, A. R., Byberg, L., \& Koupil, I. (2012). Parental influences on cardiovascular risk factors in Swedish children aged 5-14 years. European Journal of Public Health, 22, 840-847.

Kurowska, K., \& Lewandowska, A. (2012). Zachowania zdrowotne a umiejscowienie kontroli zdrowia u pacjentów $z$ rozpoznanym nadciśnieniem tętniczym [Health behaviors versus health locus of control in patients with diagnosed hypertension]. Nadciśnienie Tętnicze, 16, 296-304.

Lau, R. R., Hartman, K. A., \& Ware, J. E. (1986). Health as a value: methodological and theoretical considerations. Health Psychology, 5, 25-43.

Malik, M., Zarzycka, D., Iłżecka, J., \& Jarosz, M. (2009). Wartość zdrowia jako czynnik motywacyjny do działań prozdrowotnych [Health values as a motivational factor for health activities]. Zdrowie Publiczne, 119, 33-39.

McCann, S. J. (2005). Longevity, big five personality factors, and health behaviors: presidents from Washington to Nixon. The Journal of Psychology, 139, 273-286.

Milham, S. (2010). Historical evidence that electrification caused the 20th century epidemic of "diseases of civilization”. Medical Hypotheses, 74, 337-345.

Murphy, E. (2005). Promoting healthy behavior. Health Bulletin: Population Reference Bureau, 2, 1-29.

Norman, P., \& Bennett, P. (1996). Health locus of control. In M. Conner \& P. Norman (eds.), Predicting health behavior (pp. 62-94). Buckingham-Philadelphia: Open University Press. Source: http://psycnet. apa.org/psycinfo/1996-97268-003, from: 08.08.2010.

Ogińska-Bulik, N. (ed.). (2010). Zachowania ryzykowne i szkodliwe dla zdrowia [Risky and harmful behaviors for health]. Łódź: Wydawnictwo Akademii Humanistyczno-Ekonomicznej.

Papandonatos, G. D., Williams, D. M., Jennings, E. G., Napolitano, M. A., Bock, B. C., Dunsiger, S., \& Marcus, B. H. (2012). Mediators of physical activity behavior change: Findings from a 12-month randomized controlled trial. Health Psychology, 31, 512-520.

Raynor, D., \& Levine, H. (2009). Associations Between the Five-Factor Model of Personality and Health Behaviors Among College Students. Journal of American College Health, 58, 73-82.

Rosińska, P. (2014). Psychologiczne wyznaczniki troski o zdrowie u rodziców matych dzieci. Niepublikowana praca doktorska [Psychological indicators of self-care for health among parents with small children]. Warszawa: Instytut Psychologii, Wydział Filozofii Chrześcijańskiej.

Santulli, G. (2013). Epidemiology of cardiovascular disease in the $21^{\text {st }}$ century: Updated Numbers and Updated Facts. Journal of Cardiovascular Disease, 1, 2326-3121.
Psychological determinants of self-care for health 
Schwarzer, R. (2008). Modeling health behavior change: How to predict and modify the adoption and maintenance of health behaviors. Applied Psychology, 57, 1-29.

Smith, T. W. (2006). Personality as risk and resilence in physical health. Current Directions in Psychological Science, 15, 227-231.

Stachowska, M., Gostek, M., Klimberg, M., \& Zielińska, A. (2006). Styl życia osób w wieku 31-50 [Lifestyle of persons aged between 31-50]. Problemy Higieny i Epidemiologii, Supl. 87, 41-46.

Paulina Rosińska, Jan Tylka

Steptoe, A., \& Wardle, J. (2001). Locus of control and health behaviour revisited: a multivariate analysis of young adults from 18 countries. British Journal of Psychology, 92, 659-672.

Wallston, B. D., \& Wallston, K. A. (1978). Locus of control and health: a review of the literature. Health Education Monographs, 6, 107-117.

Weiss, G. L., \& Larsen, D. L. (1990). Health value, health locus of control, and the prediction of health protective behaviors. Social Behavior and Personality, 18, 121-136.

Zawadzki, B., Strelau, J., Szczepaniak, P., \& Śliwińska, M. (1998). Inwentarz Osobowości NEO-FFI Costy i McCrae [Personality Inventory NEO-FFI]. Warszawa: PTP. 